\title{
Aminoethoxyvinylglycine Inhibits Fruit Abscission Induced by Naphthaleneacetic Acid and Associated Relationships with Expression of Genes for Ethylene Biosynthesis, Perception, and Cell Wall Degradation in 'Delicious' Apples
}

\author{
Hong Zhu \\ Alson H. Smith, Jr. Agricultural Research and Extension Center, Virginia Polytechnic Institute and \\ State University, 595 Laurel Grove Road, Winchester, VA 22602; and the Department of Horticulture, \\ Virginia Polytechnic Institute and State University, Blacksburg, VA 24061
}

Eric P. Beers

Department of Horticulture, Virginia Polytechnic Institute and State University, Blacksburg, VA 24061

\author{
Rongcai Yuan' \\ Alson H. Smith, Jr. Agricultural Research and Extension Center, Virginia Polytechnic Institute and \\ State University, 595 Laurel Grove Road, Winchester, VA 22602
}

\begin{abstract}
AdDitional INDEX words. AVG, ethylene receptor, $\beta$-1,4-glucanase, Malus $\times$ domestica, NAA, polygalacturonase
Abstract. Effects of naphthaleneacetic acid (NAA) and aminoethoxyvinylglycine (AVG) on young fruit abscission, leaf and fruit ethylene production, and expression of genes related to ethylene biosynthesis and cell wall degradation were examined in 'Delicious' apples (Malus $\times$ domestica Borkh.). NAA at $15 \mathrm{mg} \cdot \mathrm{L}^{-1}$ increased fruit abscission and ethylene production of leaves and fruit when applied at the 11-mm stage of fruit development, whereas AVG, an inhibitor of ethylene biosynthesis, at $250 \mathrm{mg} \cdot \mathrm{L}^{-1}$ reduced $\mathrm{NAA}$-induced fruit abscission and ethylene production of leaves and fruit. NAA also increased expression of 1-aminocyclopropane-1-carboxylate (ACC) synthase genes (MdACS5A and MdACS5B), ACC oxidase gene (MdACO1), and ethylene receptor genes (MdETRIa, MdETR1b, MdETR2, MdERS1, and MdERS2) in fruit cortex and fruit abscission zones. However, AVG reduced NAA-induced expression of these genes except for MdERS2 in fruit abscission zones. NAA increased expression of the polygalacturonase gene $M d P G 2$ in fruit abscission zones but not in fruit cortex, whereas AVG reduced NAAenhanced expression of $M d P G 2$ in fruit abscission zones. The expression of $\beta-1,4$-glucanase gene $M d C e l 1$ in fruit abscission zones was decreased by NAA but was unaffected by AVG. Our results suggest that ethylene biosynthesis, ethylene perception, and the MdPG2 gene are involved in young fruit abscission caused by NAA.
\end{abstract}

Fruit thinning, which removes excessive fruit from trees at an early stage of fruit development, can improve fruit size, color, and quality; increase return bloom; and reduce alternate bearing of apple trees, thereby increasing growers' return (Byers, 2003; Childers et al., 1995; Yuan and Greene, 2000a). Because labor is very expensive, fruit thinning is usually conducted by application of chemicals. Compared with hand thinning, chemical thinning also can be done earlier in the season and more effectively increases fruit size, color, and quality (Childers et al., 1995). However, chemical thinning results are extremely variable and very difficult to predict or control because we have an incomplete understanding of the modes of action of chemical thinners (Byers, 2003).

Apple fruitlet abscission after fertilization and during "June drop" has been, at least in part, attributed to competition for carbohydrates among individual fruitlets and between fruitlets and vegetative shoots (Quilan and Preston, 1971; Yuan and Greene, 2000b). Shading or removal of spur and shoot leaves,

Received for publication 7 July 2008. Accepted for publication 23 Aug. 2008 ${ }^{1}$ Corresponding author. E-mail: yuan@vt.edu. which affects leaf photosynthesis and thereby reduces carbohydrates available to young fruit, causes extensive apple fruit abscission (Byers, 2003; Ferree and Palmer, 1982; Yuan and Greene, 2000b). Some researchers reported that the primary mechanism of fruit thinning by chemical thinners such as naphthaleneacetic acid (NAA) and 6-benzylaminopurine (6-BA) is the result of reduced carbohydrates available to developing fruit either by interference with photosynthesis (Stopar et al., 1997; Yuan and Greene, 2000a) or by reduced translocation of metabolites, including photosynthates, from leaves to the fruit (Schneider, 1978).

On the other hand, it has been suggested that chemical thinners such as NAA and 6-BA enhance apple fruitlet abscission through increased ethylene production (Curry, 1991; Dal Cin et al., 2005; McArtney, 2002; Walsh et al., 1979). The pathway of ethylene synthesis has been established in higher plants (Yang and Hoffman, 1984). Ethylene is formed from methionine through $\mathrm{S}$-adenosyl-L-methionine (SAM) to 1-aminocyclopropane-1-carboxylic acid (Yang and Hoffman, 1984). The conversion of SAM to 1-aminocyclopropane-1-carboxylate $(\mathrm{ACC})$ and $\mathrm{ACC}$ to ethylene are the 
Table 1. Gene-specific primers used for expression analysis of genes related to ethylene biosynthesis, perception, signal transduction, and cell wall degradation.

\begin{tabular}{|c|c|c|c|}
\hline Gene & Accession no. & Primer left & Primer right \\
\hline MdActin & CN938023 & 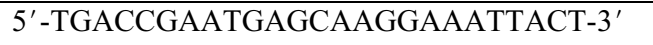 & 5'-TACTCAGCTTTGGCAATCCACATC-3' \\
\hline$M d A C S 5 B$ & AB034993 & 5'-GAATTTTGAGTGTTGGATACCTTCTTT-3' & 5'-GAACCAACATCTAAAATCCCATTGT-3' \\
\hline MdETRla & AF032448 & 5'-TTGGCCTGTGAAGAGCAGT-3' & 5'-TGCAAACCATGTAGAGCCAT-3' \\
\hline MdETRIb & AY821544 & 5'-GCACTGTGTTTGCTTGCGATT-3' & 5'-CGGGACGGCAGGTCAA-3' \\
\hline MdETR2 & DQ847145 & 5'-GTTGTGACGCGGAAAATGC-3' & 5'-AATCCAGATGAAACGGCAGTTAC-3' \\
\hline MdERS2 & AB213028 & 5'-GCTTGTTAAGGTTGGAAGAAATCTG-3' & 5'-CGGCATCGTTGAGTGTTACATT-3' \\
\hline MdCTR1 & AY670703 & 5'-ACAAGATTTTCATGCCGAAC-3' & 5'-TATGGACAAGTTTGGAGGCT-3' \\
\hline$M d P G 2$ & AB210897 & 5'-CGGTTCAGCCGACAAGTTG-3' & 5'-TACGAGTGAGGAGGAGTAGATGGA-3' \\
\hline MdCell & AY350734 & 5' -ACCAGAACGATGGATTTCCAGAT-3' & 5'-GTACGTTGCAGGCTCCGAAT-3' \\
\hline
\end{tabular}

rate-limiting steps in ethylene biosynthesis and are catalyzed by ACC synthase (ACS) and ACC oxidase (ACO), respectively (Alexander and Grierson, 2002; Wang et al., 2002). Genes encoding ACS and ACO are members of multigene families, and their expression is differentially regulated by a variety of biotic and abiotic factors (Kende, 1993; Wang et al., 2002). In apples, five ACS genes, $M d A C S 1, M d A C S 2, M d A C S 3$, $M d A C S 5 A$, and $M d A C S 5 B$, and one ACO gene, $M d A C O 1$, have been isolated and characterized (Dal Cin et al., 2005; Li and Yuan, 2008). MdACS1 and MdACOI are related to the burst of fruit ethylene production during fruit ripening in apples, whereas $M d A C S 5 B$ and $M d A C O 1$ are associated with young fruit ethylene production (Dal Cin et al., 2005; Li and Yuan, 2008).
Aminoethoxyvinylglycine is a potent inhibitor of ethylene biosynthesis through inhibiting ACS enzyme activity (Boller et al., 1979). Application of aminoethoxyvinylglycine (AVG) inhibits fruit ethylene production and expression of $M d A C S 1, M d A C S 5 A$, and $M d A C O 1$ and delays fruit ripening and preharvest fruit abscission in apples (Li and Yuan, 2008; Schupp and Greene, 2004; Yuan and Carbaugh, 2007; Yuan and Li, 2008).

After synthesis, ethylene is perceived by a family of membrane-localized receptors. In arabidopsis [Arabidopsis thaliana (L.) Heynh], there are five known ethylene receptors, ETR1, ETR2, ERS1, ERS2, and EIN4 (Wang et al., 2002). These receptors seem to undergo conformational changes on the binding of ethylene and then interact with the Raf-like serine/ threonine kinase CTR1, a negative regulator of ethylene signal transduction. The signal then passes down a partially elucidated cascade that ultimately controls a myriad of ethyleneassociated plant growth and development processes (Klee, 2004; Wang et al., 2002). In apples, it has been reported that ethylene receptor genes, MdETR1, MdETR2, MdERS1, and $M d E R S 2$, and ethylene signal transduction gene, MdCTR1, are involved in fruit ripening and young fruit abscission (Dal Cin et al., 2005; Li and Yuan, 2008).

It has been reported that concomitant with increased ethylene production is increased expression of genes and activity of enzymes associated with cell wall degradation such as $\beta$-1,4-glucanase (cellulase or EG) and polygalacturonase (PG) (Bonghi et al., 2000; Roberts et al., 2002), which causes the middle lamellae of abscission zone cells to dissolve and, ultimately, the organ to abscise. Other genes such as pathogenesis-related genes and those involved in secondary metabolism and signal transduction are also enhanced during the abscission pro-

cess (Roberts et al., 2002).
Fig. 1. Effects of NAA and AVG on (A) fruit abscission pattern and (B) total fruit abscission in 'Delicious' apples in 2007. Data are means \pm SE $(n=4)$. Different letters indicate significant differences among means according to Duncan's multiple range test $(P<0.05)$. NAA $=$ naphthaleneacetic acid; $\mathrm{AVG}=$ aminoethoxyvinylglycine. 

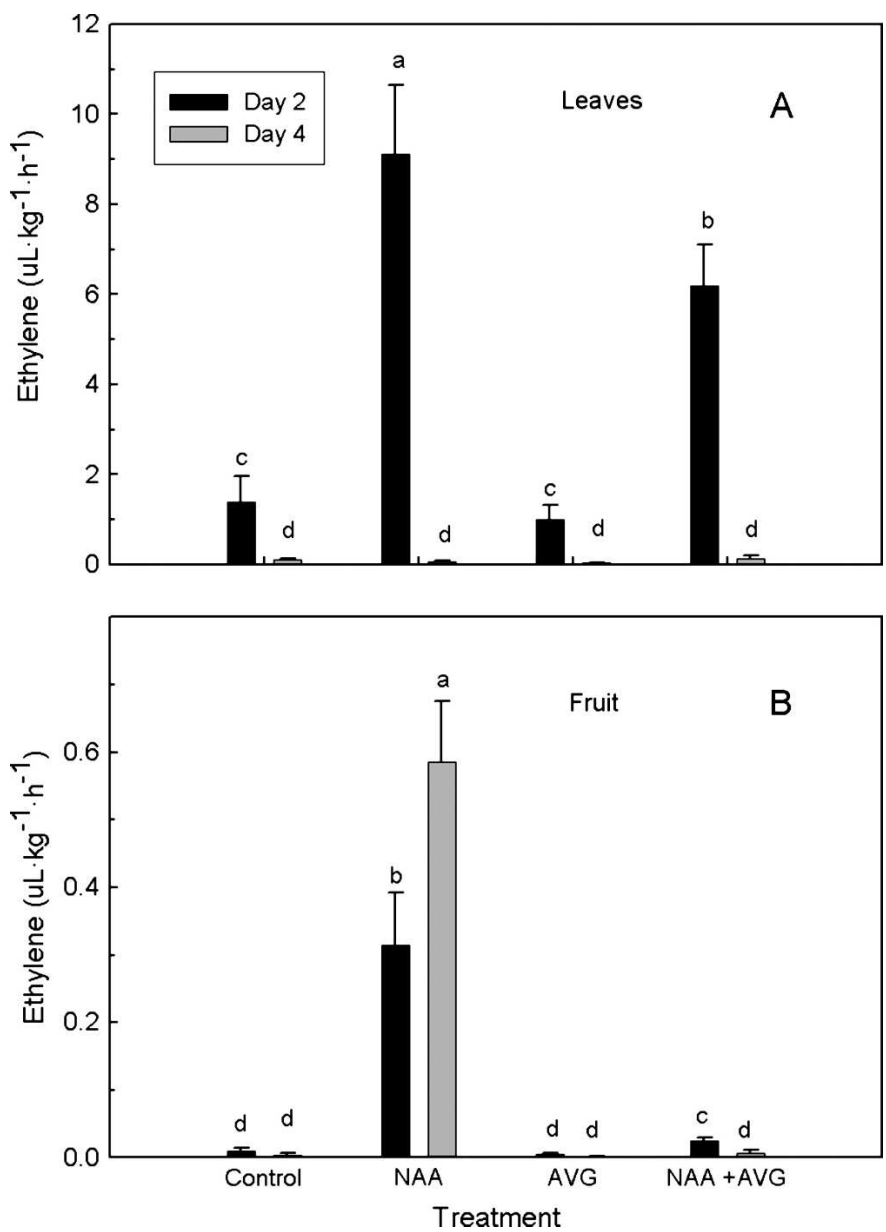

Fig. 2. Effects of NAA and AVG on (A) leaf ethylene production and (B) fruit ethylene production in 'Delicious' apples in 2007. Data are means $\pm \operatorname{SE}(n=4)$. Different letters indicate significant differences among means according to Duncan's multiple range test $(P<0.05)$. NAA $=$ naphthaleneacetic acid; $\mathrm{AVG}=$ aminoethoxyvinylglycine.

The purpose of this study was to evaluate whether ethylene biosynthesis, ethylene perception, and cell wall degradation were involved in young fruit abscission caused by the chemical thinner NAA in 'Delicious' apples.

\section{Materials and Methods}

Plant material and treatments. Sixteen 13-year-old 'Delicious' apple trees grafted on 'M.111' rootstock were selected in an orchard located at Alson H. Smith, Jr. Agricultural Research and Extension Center, Winchester, VA, and blocked into four groups of four trees each. Apple trees had an average of $2.5 \mathrm{~m}$ in canopy height and $2.7 \mathrm{~m}$ in canopy diameter. A randomized complete block design with four replications was used. One tree from each block received one of the four treatments on 14 May 2007 when fruit size was $\approx 11 \mathrm{~mm}$ in diameter. Treatments consisted of: 1) water, which served as control; 2) NAA (Fruitone N; AMVAC, Newport Beach, CA) at $15 \mathrm{mg} \cdot \mathrm{L}^{-1}$; 3) AVG (ReTain; Valent BioSciences, Libertyville, IL) at $250 \mathrm{mg} \cdot \mathrm{L}^{-1}$; and 4) NAA at $15 \mathrm{mg} \cdot \mathrm{L}^{-1}+\mathrm{AVG}$ at 250 $\mathrm{mg} \cdot \mathrm{L}^{-1}$. All spray solutions contained Silwet-77 silicone surfactant (Loveland Industries, Loveland, $\mathrm{CO}$ ) at $0.125 \%$ to improve dispersion. The surfactant had no effect on fruit and leaf ethylene production. Solutions were applied to the canopy with a lowpressure hand-wand sprayer until runoff. NAA was applied $\approx 1 \mathrm{~h}$ after application of AVG. Leaves and young fruit were dry when NAA was applied. Average daily high and low temperature in the first $3 \mathrm{~d}$ after treatment was $\approx 26 / 13{ }^{\circ} \mathrm{C}$.

In 'Golden Delicious' apples, we found that NAA, applied at the 11-mm stage of fruit development, markedly increased young fruit ethylene production and enhanced expression of genes related to ethylene biosynthesis, perception, and cell wall degradation 1, 3, and $5 \mathrm{~d}$ after treatment (H. Zhu, E. Beers, and R. Yuan, unpublished data). In this study, both leaf and young fruit samples were collected from each 'Delicious' apple tree of three replicate blocks $4 \mathrm{~d}$ after treatment $(\approx 26 \mathrm{~d}$ after full bloom). The fruit samples were immediately separated into cortex and fruit abscission zones. Fruit abscission zones were collected by cutting $1 \mathrm{~mm}$ at each side of the abscission fracture plane. Promptly after separation of fruit, all samples were frozen in liquid nitrogen and stored at $-80^{\circ} \mathrm{C}$ for extraction of RNA.

DETERMINATION OF FRUIT ABSCISSION AND ETHYLENE PRODUCTION OF FRUIT AND LEAVES. To determine fruit abscission rate, two limbs on each tree were tagged. Fruits on tagged limbs were counted just before treatment, and then fruit remaining on tagged limbs were counted every 2 or $3 \mathrm{~d}$. To determine ethylene production of fruit and leaves, 15 fruit and 20 leaves were collected from each tree 2 and $4 \mathrm{~d}$ after treatment, enclosed in 100- and 1000-mL containers, respectively, and incubated for $3 \mathrm{~h}$. One milliliter of gas sample was withdrawn from the sealed container through the rubber septum affixed to lid, and ethylene concentration was measured with a gas chromatograph equipped with an activated alumina column and FID detector (model 3700; Varian, Palo Alto, CA).

TOTAL RNA EXTRACTION AND REAL-TIME QUANTITATIVE POLYMERASE CHAIN REACTION. Total RNA was extracted from fruit abscission zones and fruit cortex as described by Li and Yuan (2008). DNA was removed from each RNA sample using the TURBO DNA-free ${ }^{\mathrm{TM}}$ Kit (Ambion, Austin, TX). Reverse transcriptase-polymerase chain reaction was performed using primers that span an intron in $M d A C O$ to confirm that each RNA sample was free of genomic DNA contamination ( $\mathrm{Li}$ and Yuan, 2008).

One microgram of total RNA was used to synthesize cDNA in a $20 \mu \mathrm{L}$ reaction volume using a High-Capacity cDNA Reverse Transcription Kit (Applied Biosystems, Foster City, CA). Real-time quantitative polymerase chain reaction (PCR) was performed using the Power SYBR Green PCR Master Mix Kit (Applied Biosystems) on an Applied Biosystems 7500 Real-Time PCR System according to the manufacturer's instructions. Gene-specific primers were designed for nonconserved areas using Primer Expression 3.0 software (Applied Biosystems) and synthesized by Integrated DNA Technologies (Coralville, IA). The primer sequences are listed in Table 1. Real-time samples were run in triplicate and the reaction volumes were $25 \mu \mathrm{L}$. Dissociation curves were generated to determine the specificity of the amplification reactions. In addition, the amplified products were sequenced as described by Li and Yuan (2008). After validation tests, normalization to actin was performed using the $\Delta \Delta \mathrm{C}_{\mathrm{T}}$ method (Applied Biosystems, 2005). 
Fruit abscission zones
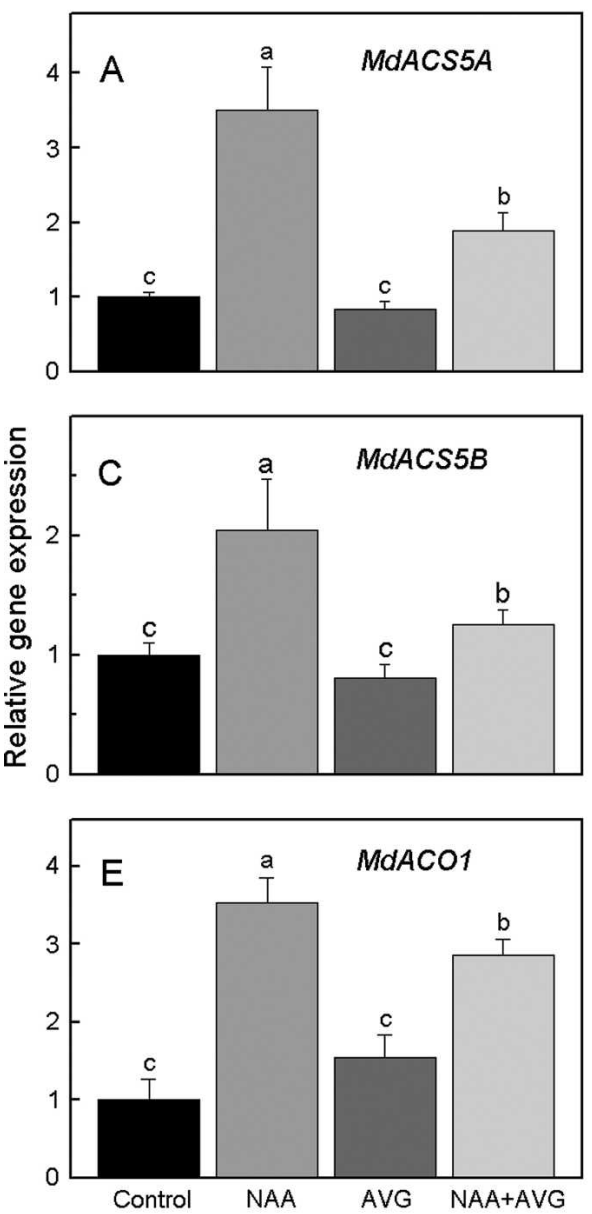

Fruit cortex
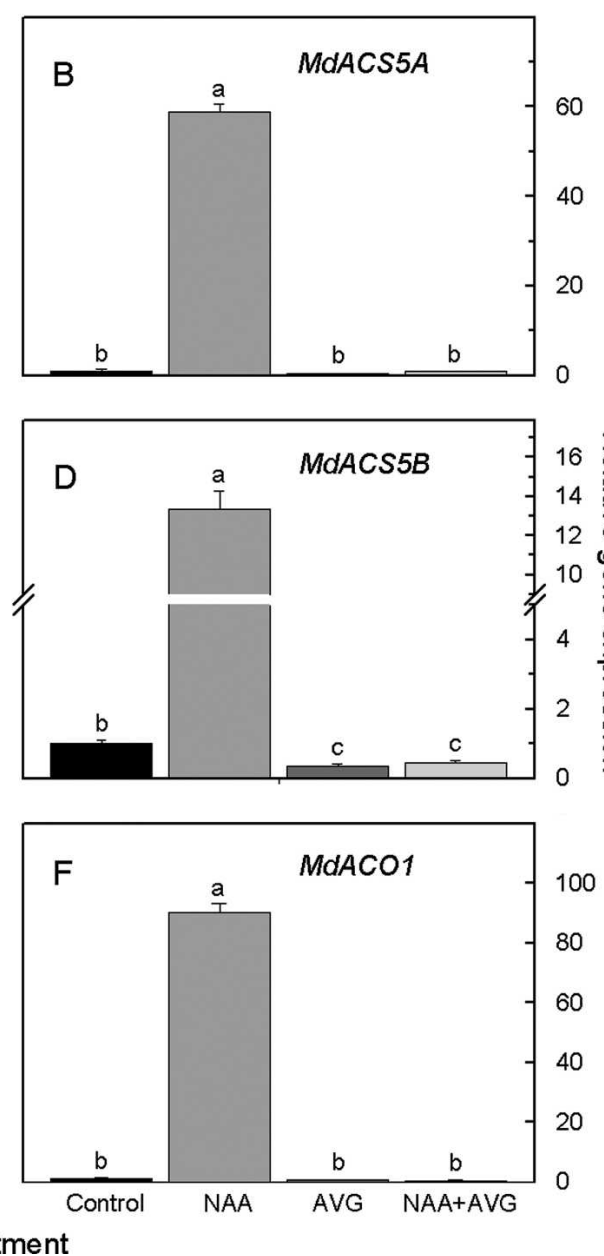

Fig. 3. Real-time quantitative polymerase chain reaction analysis of the expression of $M d A C S 5 A, M d A C S 5 B$, and $M d A C O 1$ in $(\mathbf{A}, \mathbf{C}$, and $\mathbf{E})$ fruit abscission zones and $(\mathbf{B}, \mathbf{D}$, and $\mathbf{F})$ fruit cortex from 'Delicious' apple trees $4 \mathrm{~d}$ after application of NAA and AVG. The levels of $M d A C S 5 A, M d A C S 5 B$, and $M d A C O 1$ transcripts were normalized using actin. Data are means $\pm \mathrm{SE}(\mathrm{n}=3)$. The values of $M d A C S 5 A, M d A C S 5 B$, and $M d A C O 1$ in fruit abscission zones and fruit cortex from water-treated control 'Delicious' apple trees were arbitrarily set to 1. Different letters indicate significant differences among means according to Duncan's multiple range test $(P<$ 0.05). NAA = naphthaleneacetic acid; AVG = aminoethoxyvinylglycine

STATISTICAL ANALYSES. Statistical analyses included analysis of variance and Duncan's multiple range test. SAS software for PC (SAS Institute, Cary, NC) was used to analyze the results.

\section{Results}

EFfect of NAPHThaleneacetic ACid AND AMinoETHOXYVINYLGLYCINE ON FRUIT ABSCISSION AND ETHYLENE PRODUCTION OF FRUIT AND LEAVES. NAA at $15 \mathrm{mg} \cdot \mathrm{L}^{-1}$ effectively increased fruit abscission, whereas $A V G$ at $250 \mathrm{mg} \cdot \mathrm{L}^{-1}$ reduced NAA-enhanced fruit abscission in 'Delicious' apples (Fig. 1AB). The rate of NAA-induced fruit abscission peaked $\approx 14$ $\mathrm{d}$ after treatment. Compared with the water-treated control, ethylene production of NAA-treated leaves increased $\approx 9$-fold $2 \mathrm{~d}$ after treatment (Fig. 2A). However, there was no difference in leaf ethylene production between the control and NAA $4 \mathrm{~d}$ after treatment. AVG reduced NAA-induced leaf ethylene production $2 \mathrm{~d}$ after treatment. Fruit ethylene production was also stimulated by NAA 2 and $4 \mathrm{~d}$ after treatment (Fig. 2B). As was observed for leaves, there was no difference in fruit ethylene

production between control and the AVG-only treatment. AVG virtually eliminated NAA-induced fruit ethylene production.

EFFECT OF NAPHTHALENEACETIC ACID AND AMINOETHOXYVINYLGLYCINE ON EXPRESSION OF GENES ENCODING ENZYMES INVOLVED IN ETHYLENE BIOSYNTHESIS. Very low or no expression of $M d A C S 1, M d A C S 2$, and $M d A C S 3$ was detected in fruit abscission zones and fruit cortex (data not shown). The expression of $M d A C S 5 A, M d A C S 5 B$, and $M d A C O 1$ in fruit cortex and fruit abscission zones was increased by NAA application (Fig. 3A-F). The cortex of fruit from trees treated with AVG alone had lower levels of $M d A C S 5 B$ transcripts than that from water-treated control trees. However, there was no significant difference in the levels of $M d A C S 5 B$ in fruit abscission zones between AVG alone and the watertreated control. There was no difference in the levels of MdACS5A and $M d A C O 1$ transcripts in fruit cortex and fruit abscission zones between the water-treated control and AVG alone either. NAAinduced expression of $M d A C S 5 A$, $M d A C S 5 B$, and $M d A C O 1$ in fruit cortex and fruit abscission zones was decreased by AVG.

EFFECT OF NAPHTHALENEACETIC ACID AND AMINOETHOXYVINYLGLYCINE ON EXPRESSION OF GENES ENCODING ETHYLENE RECEPTORS AND ETHYLENE SIGNAL TRANSDUCTION KINASE CTR1. The levels of MdETRIa, MdETR1b, and MdETR2 transcripts in fruit abscission zones and fruit cortex were increased by NAA (Fig. 4). Expression of MdETR $1 a$ and MdETR $1 b$ in fruit cortex and fruit abscission zones was unaffected by AVG alone. AVG alone increased expression of MdETR2 in fruit abscission zones but not in fruit cortex. NAA-induced expression of MdETRla, $M d E T R 1 b$, and MdETR2 in fruit abscission zones and fruit cortex was reduced by AVG.

The levels of MdERS1, MdERS2, and MdCTR1 transcripts in fruit abscission zones and fruit cortex were increased by NAA (Fig. 5). AVG alone increased expression of MdERS2 in fruit abscission zones, but it had no effect on expression of MdERS2 in fruit cortex. AVG alone did not affect expression of MdERS1 and $M d C T R 1$ in fruit abscission zones and fruit cortex. NAA-induced expression of MdERS1, MdERS2, and MdCTR1 in fruit cortex was reduced by AVG. AVG reduced NAA-induced expression of $M d E R S 1$ but not of MdERS2 or MdCTR1 in fruit abscission zones.

EFFECT OF NAPHTHALENEACETIC ACID AND AMINOETHOXYVINYLGLYCINE ON EXPRESSION OF GENES ENCODING ENZYMES INVOLVED IN CELL WALL DEGRADATION IN 'DELICIOUS' APPLES. The expression of MdCell in fruit abscission zones and fruit 


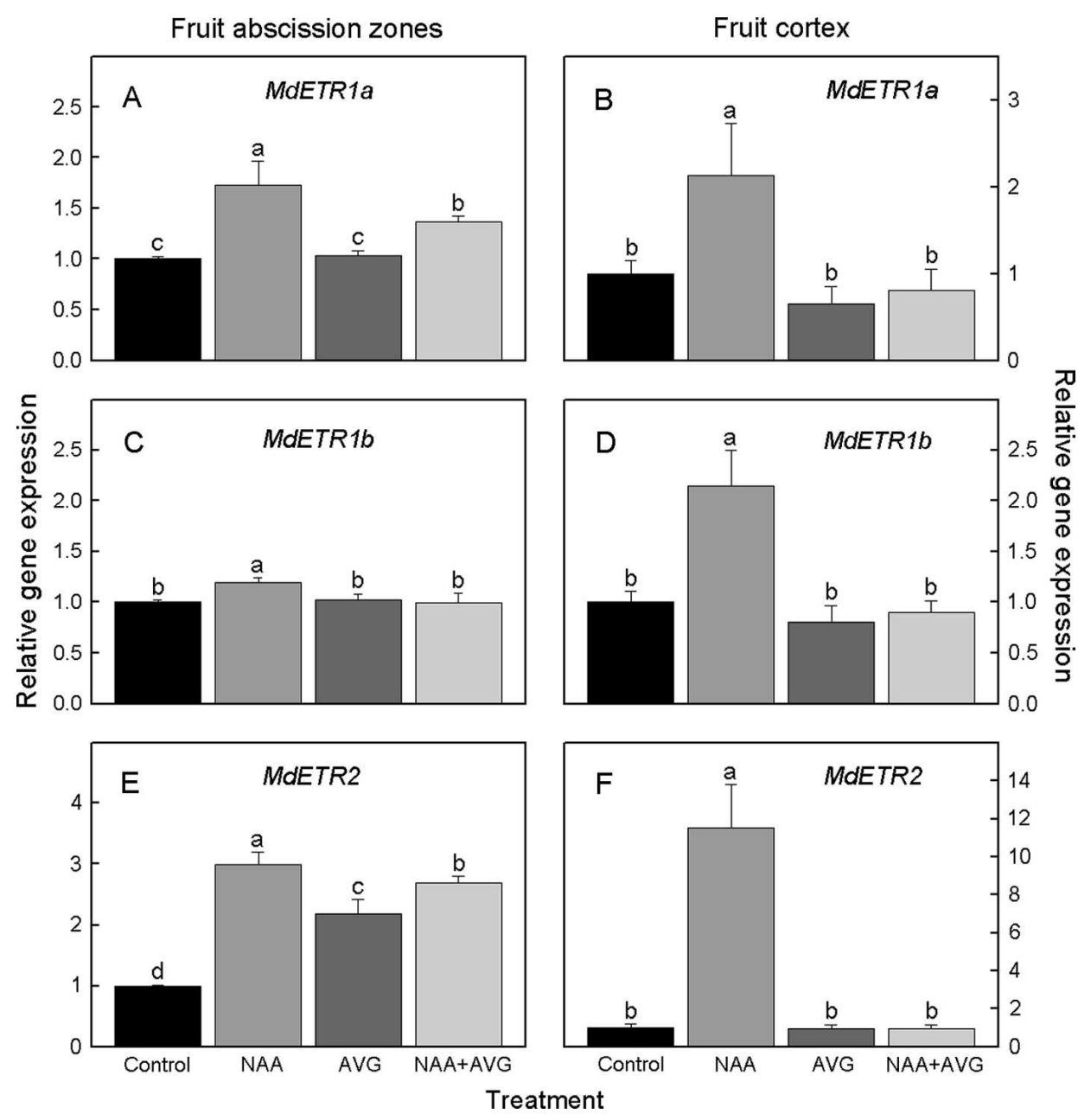

Fig. 4. Real-time quantitative polymerase chain reaction analysis of expression of MdETRIa, MdETR1b, and $M d E T R 2$ in $(\mathbf{A}, \mathbf{C}$, and $\mathbf{E})$ fruit abscission zones and $(\mathbf{B}, \mathbf{D}$, and $\mathbf{F})$ fruit cortex from 'Delicious' apple trees $4 \mathrm{~d}$ after application of NAA and AVG. The levels of MdETRla, MdETR1b, and MdETR2 transcripts were normalized using actin. Data are means \pm SE $(\mathrm{n}=3)$. The values of MdETR $1 a, M d E T R 1 b$, and MdETR2 in fruit abscission zones and fruit cortex from water-treated control 'Delicious' apple trees were arbitrarily set to 1. Different letters indicate significant differences among means according to Duncan's multiple range test $(P<0.05) . \mathrm{NAA}=$ naphthaleneacetic acid; $\mathrm{AVG}=$ aminoethoxyvinylglycine.

cortex was decreased by NAA but was unaffected by AVG (Fig. 6A-B). Expression of MdPG1 was not detected in fruit abscission zones and fruit cortex (data not shown). $M d P G 2$ expression in fruit abscission zones was increased by NAA but was unaffected by AVG alone (Fig. 6C). $A V G$ reduced NAA-induced expression of $M d P G 2$ in fruit abscission zones. Expression of $M d P G 2$ in fruit cortex was unaffected by NAA but reduced by AVG and NAA + AVG.

\section{Discussion}

In this study, NAA increased ethylene production of young fruit and leaves and increased young fruit abscission in 'Delicious' apples. This is consistent with previous reports that ethylene production of young fruit and leaves increased rapidly in response to postbloom thinning spray of NAA (Curry, 1991; Dal Cin et al., 2005; McArtney, 2002; Walsh et al., 1979). We expanded on this observation and showed that NAA-induced ethylene production of young fruit and leaves and young fruit abscission were reduced by AVG, a well-known inhibitor of ACS activity (Boller et al., 1979). These results suggest that NAA-induced young fruit abscission is associated with ethylene biosynthesis in apples.

It has been suggested that regulation of ethylene biosynthesis by various stresses and endogenous signals is mainly through the differential expression of ACS and ACO genes (Kende, 1993). Auxin stimulates ethylene production by enhancing ACS expression in various plant species (Abel and Theologis, 1996; Li and Yuan, 2008). Our results showed that expression of $M d A C S 5 A, M d A C S 5 B$, and $M d A C O 1$ increased significantly in NAA-treated fruit cortex and fruit abscission zones, whereas very low or no expression of $M d A C S 1$, $M d A C S 2$, and $M d A C S 3$ was detected. On the other hand, AVG effectively reduced NAA-enhanced expression of $M d A C S 5 A$, $M d A C S 5 B$, and $M d A C O 1$. These results suggest that $M d A C S 5 A$, $M d A C S 5 B$, and $M d A C O 1$ but not $M d A C S 1, M d A C S 2$, or $M d A C S 3$ are related to NAA-induced ethylene production of young fruit and young fruit abscission in 'Delicious' apples.

Our results showed that expression of ethylene receptor genes MdETR1a, MdETR1b, MdETR2, and MdERS1 in fruit abscission zones and fruit cortex and MdERS2 in fruit cortex was increased by NAA, but AVG reduced NAA-induced expression of these genes, suggesting that NAA-induced expression of these receptors may be dependent on increased ethylene production. Other investigators have also suggested that the increase in the levels of overall receptor mRNA during fruit abscission may be a natural response to increased ethylene biosynthesis (Dal Cin et al., 2005; Kevany et al., 2007; Klee, 2004). Moreover, that the application of AVG reduced NAA-induced expression of MdETRla, $M d E T R 1 b, M d E T R 2$, and MdERS1 genes in fruit abscission zones and NAA-induced fruit abscission is suggestive of a role for these ethylene receptors in NAA-induced young fruit abscission in 'Delicious' apples. A similar correlation between abscission and increased expression of ethylene receptor genes in abscission zones has been reported in flowers of tomato (Solanum lycopersicum L.) (Lashbrook et al., 1998; Whitelaw et al., 2002) and young fruit of apples (Dal Cin et al., 2005). Also consistent with our finding is the observation that reduction of LeETRI transcript levels by antisense LeETRI delayed the abscission of flowers and leaves in tomato (Whitelaw et al., 2002). However, the observed correlation seems contradictory to the model that ethylene receptors negatively 
Fruit abscission zones
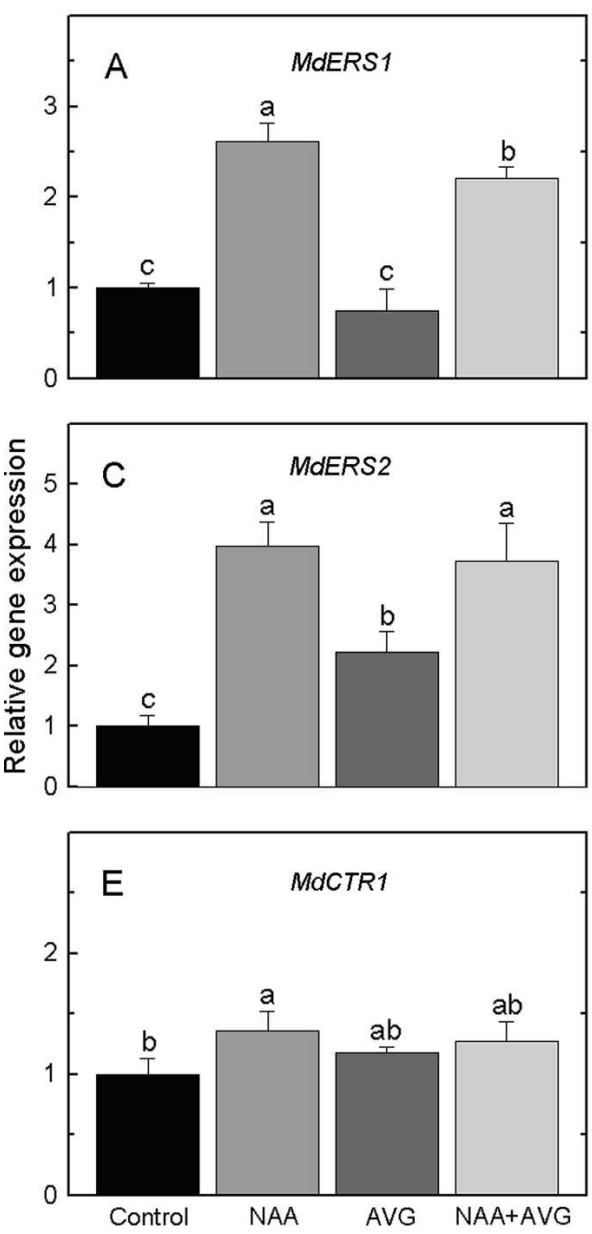

Treatment
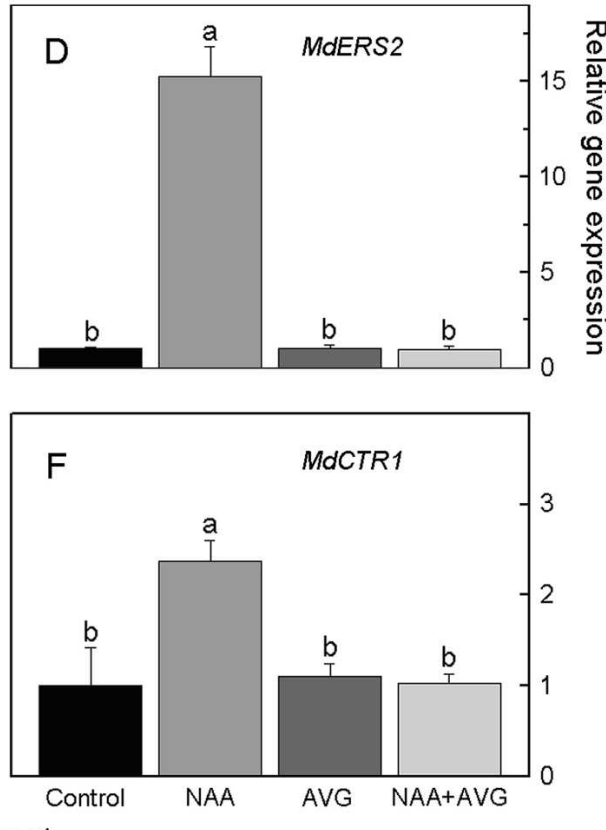

Fig. 5. Real-time quantitative polymerase chain reaction analysis of expression of MdERS1, MdERS2, and $M d C T R 1$ in $(\mathbf{A}, \mathbf{C}$, and $\mathbf{E})$ fruit abscission zones and $(\mathbf{B}, \mathbf{D}$, and $\mathbf{F})$ fruit cortex from 'Delicious' apple trees $4 \mathrm{~d}$ after application of NAA and AVG. The levels of MdERS1, MdERS2, and MdCTR1 transcripts were normalized using actin. Data are means $\pm \mathrm{SE}(\mathrm{n}=3)$. The values of MdERS1, MdERS2, and MdCTR1 in fruit abscission zones and fruit cortex from water-treated control 'Delicious' apple trees were arbitrarily set to 1 . Different letters indicate significant differences among means according to Duncan's multiple range test $(P<0.05)$. NAA $=$ naphthaleneacetic acid; $\mathrm{AVG}=$ aminoethoxyvinylglycine .

regulate ethylene responses and there is an inverse relationship between receptor levels and ethylene sensitivity of a tissue (Hua and Meyerowitz, 1998; Klee, 2004). Further work will be necessary to determine the relationship between the levels of ethylene receptor proteins in abscission zones and fruit abscission.

It has been well documented that an increase in PG and cellulase activities is usually associated with fruit abscission (Bonghi et al., 2000; Li and Yuan, 2008). No expression of $M d P G 1$ was detected in the abscission zones of young 'Delicious' apple fruit regardless of treatment (data not shown), suggesting that $M d P G 1$ is not related to young fruit abscission in apples. Similarly, Li and Yuan (2008) reported that MdPG1 is not involved in mature fruit abscission in apples. On the other hand, NAA increased MdPG2 expression in fruit abscission zones, but the increase was reduced by AVG. These results suggest that $M d P G 2$ is related to NAA-induced young fruit abscission. Our results also showed that expression MdCell, which encodes cellulase, was significantly decreased by NAA but unaffected by AVG in fruit abscission zones. This indicates that $M d C e l 1$ is unlikely involved in young fruit abscission induced by NAA.

Carbohydrates and fruit ethylene production play a critical role in young fruit abscission in apples (Byers, 2003; Curry, 1991; McArtney, 2002; Stopar et al., 1997; Walsh et al., 1979; Yuan and Greene, 2000a). However, the relationship between carbohydrates and fruit ethylene production is not clear. Recent studies have revealed that sugars not only provide carbon and energy, but also play a pivotal role as signaling molecules in plants that integrate external environment conditions with intrinsic developmental programs modulated by multiple plant hormones (Rolland et al., 2006; Thimm et al., 2004). DNA microarray analysis showed that shading or low sugar concentrations upregulated genes involved in biosynthesis and signaling of abscisic acid (ABA) and ethylene in arabidopsis plants (Cheng et al., 2002; Kim and Arnim, 2006; Thimm et al., 2004), whereas application of glucose downregulated genes upregulated by both shading and ABA (Kim and Arnim, 2006). It also has been reported that defoliation- or shading-induced young fruit abscission was preceded by an increase in the levels of ABA and ACC in citrus [Citrus unshiu (Mak.) Marc.] (Gomez-Cadenas et al., 2000; Iglesias et al., 2006). Therefore, it is possible that NAA not only directly increases fruit ethylene production by increasing expression of $M d A C S 5 A$ and MdACS5B, but also indirectly increases fruit ethylene production through increasing biosynthesis and signaling of $\mathrm{ABA}$ and ethylene by reducing photosynthesis and carbohydrate levels. More research work will be necessary to determine the relationship between carbohydrate shortage and young fruit ethylene production.

Unlike the positive effect NAA has on abscission of young apple fruit, NAA reduces mature apple fruit abscission although it increases fruit ethylene production and fruit softening ( $\mathrm{Li}$ and Yuan, 2008). Using real-time quantitative PCR, Li and Yuan (2008) found that NAA reduced mature apple fruit abscission by inhibiting expression of $M d P G 2$ in fruit abscission zones, increased mature fruit ethylene production by increasing expression of MdACS1 and MdACO1, and enhanced mature fruit softening by increasing expression of $M d P G 1$ in fruit cortex. Further efforts are needed to determine how NAA increases expression of $M d P G 2$ in abscission zones of young fruit but inhibits its expression in mature fruit abscission zones.

In summary, our results showed that NAA increased young apple fruit abscission through increasing expression of 


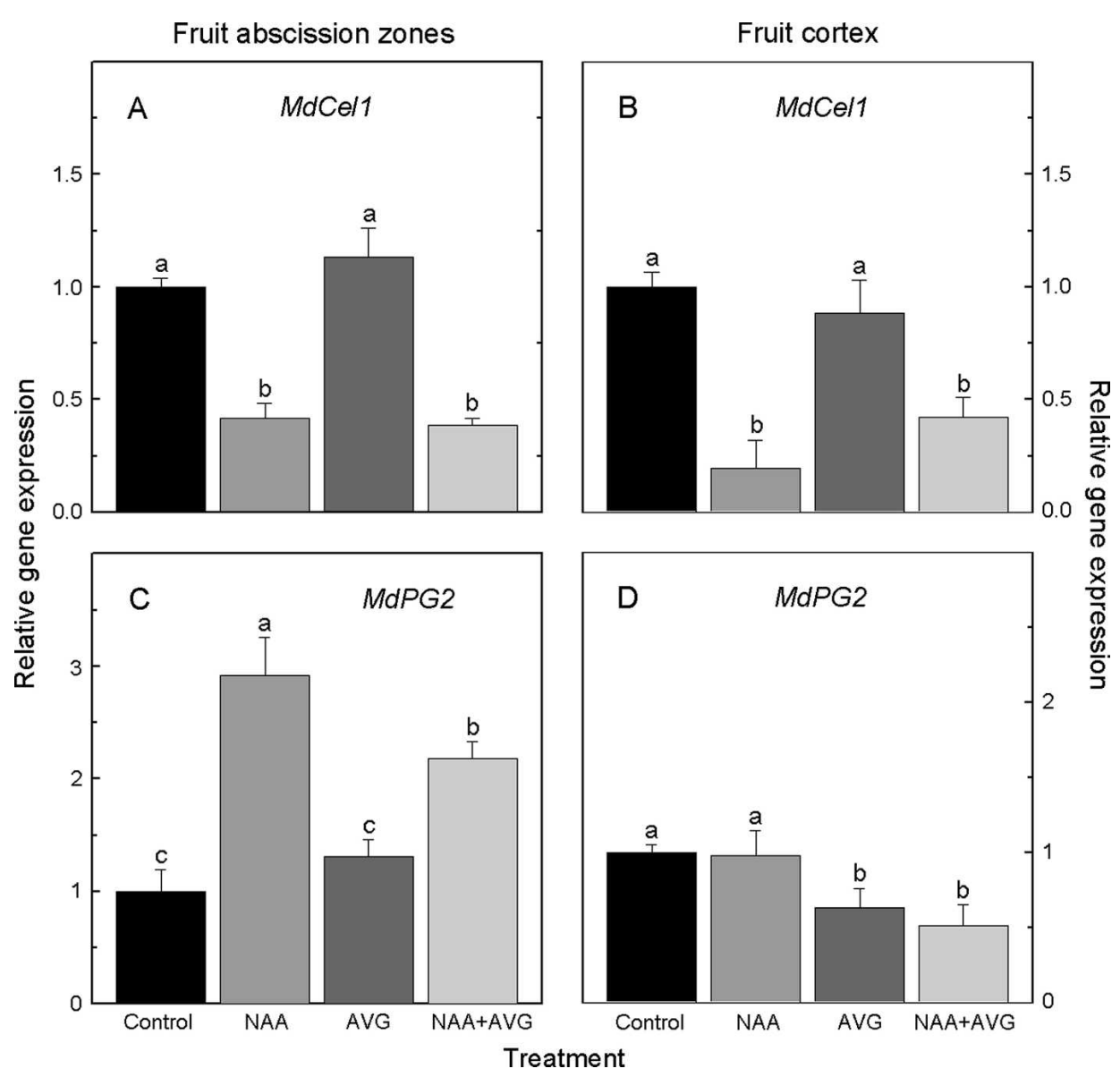

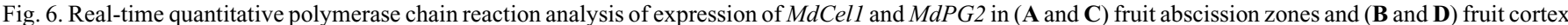
from 'Delicious' apple trees $4 \mathrm{~d}$ after application of NAA and AVG. The levels of MdCell and MdPG2 transcripts were normalized using actin. Data are means \pm SE ( $\mathrm{n}=3)$. The values of MdCel1 and MdPG2 in fruit abscission zones and fruit cortex from water-treated control 'Delicious' apple trees were arbitrarily set to 1 . Different letters indicate significant differences among means according to Duncan's multiple range test $(P<0.05)$. NAA $=$ naphthaleneacetic acid; AVG $=$ aminoethoxyvinylglycine.

$M d A C S 5 A, M d A C S 5 B$, and MdACO1; fruit ethylene production; and expression of MdETRIa, MdETRIb, MdETR2, MdERS1, MdERS2, and MdPG2 in fruit abscission zones. In contrast, AVG reduced NAA-induced young apple fruit abscission by inhibiting fruit ethylene production and expression of MdACS5A, MdACS5B, MdACO1, MdETRIa, MdETRIb, MdETR2, MdERS1, and MdPG2 in fruit abscission zones.

\section{Literature Cited}

Abel, S. and A. Theologis. 1996. Early genes and auxin action. Plant Physiol. 111:9-17.

Alexander, L. and D. Grierson. 2002. Ethylene biosynthesis and action in tomato: A model for climacteric fruit ripening. J. Expt. Bot. 53:2039-2055.

Applied Biosystems. 2005. Guide to performing relative quantitation of gene expression using real-time quantitative PCR. Applied Biosystems, Foster City, CA.

Boller, T., R.C. Herner, and H. Kende. 1979. Assay for and enzymatic formation of an ethylene precursor 1-aminocyclopropane-1-carboxylic acid. Planta 145:293-303.

Bonghi, C., P. Tonutti, and A. Ramina. 2000. Biochemical and molecular aspects of fruitlet abscission. Plant Growth Regulat. 31:35-42.

Byers, R.E. 2003. Flower and fruit thinning and vegetative: Fruiting balance, p. 409-436. In: D.C. Ferree and I.J. Warrington (eds.).
Apples: Botany, production and uses. CABI Publishing, Cambridge, MA.

Cheng, W., A. Endo, L. Zhou, J. Penney, H. Chen, A. Arroyo, P. Leon, E. Nambara, T. Asami, M. Seo, T. Koshiba, and J. Sheen. 2002. A unique short-chain dehydrogenase/reductase in Arabidopsis glucose signaling and abscisic acid biosynthesis and functions. Plant Cell 14:2723-2743.

Childers, N.F., J.R. Morris, and G.S. Sibbett. 1995. Modern fruit science. 10th Ed. Horticultural Publications, Gainseville, FL.

Curry, E.A. 1991. NAA-induced ethylene and ACC in 'Delicious' spur tissues: Changes with temperature and time. J. Amer. Soc. Hort. Sci. 116:846-850.

Dal Cin, V., M. Danesin, A. Boschetti, A. Dorigoni, and A. Ramina. 2005. Ethylene biosynthesis and perception in apple fruitlet abscission (Malus domestica L. Borkh). J. Expt. Bot. 56:2995-3005.

Ferree, D.C. and J.W. Palmer. 1982. Effects of spur defoliation and ringing during bloom on fruiting, fruit mineral level, and net photosynthesis of Golden Delicious apples. J. Amer. Soc. Hort. Sci. 107:1182-1186.

Gomez-Cadenas, A., J. Mehouachi, F.R. Tadeo, E. Primo-Millo, and M. Talon. 2000. Hormonal regulation of fruitlet abscission induced by carbohydrate shortage in citrus. Planta 210:636-643.

Hua, J. and E.M. Meyerowitz. 1998. Ethylene responses are negatively regulated by a receptor gene family in Arabidopsis thaliana. Cell 94:261-271. 
Iglesias, D.J., F.R. Tadeo, E.P. Millo, and M. Talon. 2006. Carbohydrate and ethylene levels related to fruitlet drop through abscission zone A in citrus. Trees (Berl.) 20:348-355.

Kende, H. 1993. Ethylene biosynthesis. Annu. Rev. Plant Physiol. Plant Mol. Biol. 44:283-307.

Kevany, B.M., D.M. Tieman, M.G. Taylor, V. Dal Cin, and H.J. Klee. 2007. Ethylene receptor degradation controls the timing of ripening in tomato fruit. Plant J. 51:458-467.

Kim, B.H. and A.G. Arnim. 2006. The early dark-response in Arabidopsis thaliana revealed by cDNA microarray analysis. Plant Mol. Biol. 60:321-342.

Klee, H.J. 2004. Ethylene signal transduction. Moving beyond Arabidopsis. Plant Physiol. 135:660-667.

Lashbrook, C.C., D.M. Tieman, and H.J. Klee. 1998. Differential regulation of the tomato ETR gene family throughout plant development. Plant J. 15:243-252.

Li, J. and R. Yuan. 2008. NAA and ethylene regulate expression of genes related to ethylene biosynthesis, perception and cell wall degradation during fruit abscission and ripening in 'Delicious' apples. J. Plant Growth Regul. 27:283-295.

McArtney, S.J. 2002. Ethylene evolution from detached apple spurs in response to chemical thinners. HortScience 37:662-665.

Quilan, J.D. and A.P. Preston. 1971. The influence of shoot competition on fruit retention and cropping of apple trees. J. Hort. Sci. 46:525-534.

Roberts, J.A., K.A. Elliott, and Z.H. Gonzalez-Carranza. 2002. Abscission, dehiscence, and other cell separation process. Annu. Rev. Plant Biol. 53:131-158.

Rolland, F., E. Baena-Gonzalez, and J. Sheen. 2006. Sugar sensing and signaling in plants: Conserved and novel mechanisms. Annu. Rev. Plant Biol. 57:675-709.

Schneider, G.W. 1978. Abscission mechanism studies with apple fruitlets. J. Amer. Soc. Hort. Sci. 103:455-458.

Schupp, J.R. and D.W. Greene. 2004. Effect of aminoethoxyvinylglycine $(\mathrm{AVG})$ on preharvest drop, fruit quality, and maturation of
'McIntosh' apples. I. Concentration and timing of dilute applications of AVG. HortScience 39:1030-1035.

Stopar, M., B.L. Black, and M.J. Bukovac. 1997. The effect of NAA and BA on $\mathrm{CO}_{2}$ assimilation by shoot leaves of spur-type 'Delicious' and 'Empire' apple trees. J. Amer. Soc. Hort. Sci. 122:837-840.

Thimm, O., O. Blasing, Y. Gibon, A. Nagel, S. Meyer, P. Kruger, J. Selbig, L.A. Muller, S.Y. Rhee, and M. Stitt. 2004. Mapman: A userdriven tool to display genomics data sets onto diagrams of metabolic pathways and other biological processes. Plant J. 37:914-939.

Wang, K.L.C., H. Li, and J.R. Ecker. 2002. Ethylene biosynthesis and signaling networks. Plant Cell 14:S131-S151.

Walsh, C.S., H.J. Swartz, and L.J. Edgerton. 1979. Ethylene evolution in apple following post-bloom thinning sprays. HortScience 14:704-706. Whitelaw, C.A., N.N. Lyssenko, L. Chen, D. Zhou, A.K. Mattoo, and M.L. Tucker. 2002. Delayed abscission and shorter internodes correlate with a reduction in the ethylene receptor LeETR1 transcript in transgenic tomato. Plant Physiol. 128:978-987.

Yang, S.F. and N.E. Hoffman. 1984. Ethylene biosynthesis and its regulation in higher plants. Annu. Rev. Plant Physiol. 35:155-189.

Yuan, R. and D.H. Carbaugh. 2007. Effects of NAA, AVG, and 1-MCP on ethylene biosynthesis, preharvest fruit drop, fruit maturity, and quality of 'Golden Supreme' and 'Golden Delicious' apples. HortScience 42:101-105.

Yuan, R. and D.W. Greene. 2000a. Benzyladenine as a chemical thinner for 'McIntosh' apples. I. Fruit thinning effects and associated relationships with photosynthesis, assimilate translocation, and nonstructural carbohydrates. J. Amer. Soc. Hort. Sci. 125:169-176.

Yuan, R. and D.W. Greene. 2000b. Benzyladenine as a chemical thinner for 'McIntosh' apples. II. Effects of benzyladenine, bourse shoot tip removal, and leaf number of fruit retention. J. Amer. Soc. Hort. Sci. 125:177-182.

Yuan, R. and J. Li. 2008. Effects of sprayable 1-MCP, AVG, and NAA on ethylene biosynthesis, preharvest fruit drop, fruit maturity, and quality of 'Delicious' apples. HortScience 43:1454-1460. 